\title{
Chatterpix Kids: A Potential Mobile App for Helping Primary ESL Pupils Improve Their Speaking Fluency
}

\author{
Thirumangai Rajendran \\ Universiti Kebangsaan Malaysia, Selangor, Malaysia \\ https://orcid.org/0000-0002-9113-5669 \\ Melor Md Yunus \\ Universiti Kebangsaan Malaysia, Selangor, Malaysia \\ https:// orcid.org/0000-0001-7504-7143
}

\begin{abstract}
The mastery of all four language skills has become one of the topmost priorities among English as a Second Language (ESL) learners worldwide. Despite multiple efforts taken to master the necessary skills, speaking remains to the most challenging skill for many Malaysian ESL learners. Previous studies suggest that Mobile-assisted Language Learning (MALL) for speaking has taken its first steps in Malaysian tertiary and secondary levels of education. However, there is still a paucity of research done on MALL at the primary level. The present case study therefore sought to fill in the gap by exploring how the ChatterPix Kids mobile app has helped 5 purposively selected Year 3 primary school pupils develop their speaking fluency. This was done through speaking practices conducted over 12 speaking lessons during the Movement Control Order (MCO) from their perspective. The pupils' responses obtained through the semi-structured interviews were triangulated using the responses obtained from them through both a focus group and their parents' feedback obtained through an open-ended questionnaire. The findings were thematically analysed. Seven themes were highlighted which indicate the crucial need to incorporate MALL for speaking among Malaysian primary school pupils. Further studies are recommended to be done on how ChatterPix Kids could be exploited when learning other language skills such as listening, reading, and writing. So far as the study's limitations are concerned, there is a need to investigate how the pupils' confidence could be sustained in the absence of the app when speaking in public.
\end{abstract}

Keywords: English as a Second Language (ESL); Mobile-assisted Language Learning (MALL); speaking; ChatterPix Kids; mobile app 


\section{Introduction}

The current demands of $21^{\text {st }}$ century skills expect an individual to be proficient in English in order to be distinguished as a 'global player'. This has raised growing concerns in the education system worldwide, particularly in countries which regard English as a Second Language (ESL) (Rao, 2019). Correspondingly, the term 'bilingual proficiency' has been coined by the Malaysian Ministry of Education (MOE). This is the expectation that every Malaysian child should be proficient in both the Malay and English languages by the end of the 12-year schooling process. The MOE aspires to create students who are at least 'operationally proficient' in English as stipulated in the Malaysian Education Blueprint (2013 - 2025). According to the current Common European Framework of Reference for Languages (CEFR), which is used to describe a learners' language ability against the international standard, being operationally proficient refers to the ability to use the language flexibly and effectively for social, academic, and professional purposes. At this point, Malaysian ESL learners are expected to have improved their communicative competence based on the 6 levels stipulated in the CEFR. This puts further emphasis on speaking (Azlan et al., 2019).

Amid achieving the above aspiration, the speaking skill is often regarded as one of the most demanding and challenging of the four skills whereby many Malaysian ESL learners are still struggling to achieve fluency when speaking (Darmi \& Albion, 2017; Leong \& Ahmadi, 2017; Azlan et al., 2019; Paneerselvam \& Mohamad, 2019; Precintha et al., 2019). Recent studies suggest that this scenario is not only evident among adult ESL learners but that it is also an obtrusive issue among most primary ESL pupils in Malaysia (Nijat et al., 2019; Samat et al., 2019). Generally, studies done in both global and local contexts have addressed similar factors contributing towards the poor speaking fluency among ESL learners. First, the learners are identified to be the victims of common psychological factors such as a lack of motivation and poor self-confidence, in addition to anxiety, a fear of criticism and inhibition (Leong \& Ahmadi 2017; Abugohar et al. 2019; Azlan et al., 2019; Paneerselvam \& Mohamad 2019; Nijat et al., 2019; Samat et al., 2019; Tonekaboni, 2019; Yin, 2019). A lack of speaking practice opportunities in their immediate surroundings is also prominent, as learners prefer using their mother tongue in their daily conversations outside the classroom (Shuangjiang \& Jitpanat, 2017; Lutfi, 2020). Lutfi (2020) found that most of the classroom time is spent learning structures and forms instead of focusing on communicative activities, leaving a very limited amount of time for each learner to practice speaking the target language.

This phenomenon was evident among the pupils chosen for this study before they started using the ChatterPix Kids mobile app for speaking practice. They were observed to hesitate and have fragmented speech while speaking due to difficulties retrieving the lexical items, encoding the grammatical message, and correcting their own output. This condition makes them hesitate while speaking with frequent uses of pause fillers like "umm", "mmm", "uhh", "errr". They also tend to translate, repeat, self-correct, and rephrase words. Due to these issues in speaking fluency, the pupils scored in the lower bands in their CEFR classroombased speaking assessment. This issue becomes even more challenging to 
intervene in as schools have been closed during the Movement Control Order (MCO) due to Covid-19.

Over the past few decades, different technologies have been used as tools for enhancing the speaking skill among the ESL learners worldwide. One of the areas that has indicated positive outcomes is Mobile-assisted Language Learning (MALL). In Malaysia, a few studies have explored MALL at the tertiary education level in universities and colleges (Hashim et al. 2016; Ismail et al., 2019; Precintha et al., 2019). However, to the researchers' best knowledge, there has only been one study done on MALL at the primary level to date (Azlan et al., 2019). This further supports Ismail et al.'s (2019) claim that there is still a paucity of research investigating the implementation of MALL in the Malaysian primary school context. Nevertheless, studies focusing on MALL, particularly on speaking among Malaysian ESL learners (Darmi \& Albion, 2017; Azlan et al., 2019), are still limited.

A review done by Hashim et al. (2017) claims that mobile devices are finding their way into classrooms through the students' pockets. This correlates with the Malaysian Communications and Multimedia Commission's (2017) survey which reported that telephones were the highest medium of communication being used. Apparently, $83.2 \%$ of children aged 5 to 17 were Internet users, and $93 \%$ of the surfed the Internet using their smartphones. This study intends to fill in the literature gap by contributing meaningful insights to the field of MALL for those speaking predominantly in the Malaysian primary school context. The purpose of this case study is to explore how the ChatterPix Kids mobile app could help 5 purposively selected Year 3 primary ESL pupils in developing their speaking fluency through speaking practices conducted over 12 speaking lessons during the MCO from their perspective. These pupils were noticed to exhibit improved speaking fluency and positive language behaviours after using the ChatterPix Kids mobile app as a tool for practicing speaking. The pupils' parents' views were also explored as they had witnessed their child's speaking practices which take place in informal learning situations. The pupils' perspectives were obtained through semi-structured interviews and a focus group while their parents' views obtained through an open-ended questionnaire. These views were triangulated to see if there was any possible relationship that could further strengthen the findings related to the current study's proposed research question:

i. How does the use of the ChatterPix Kids mobile app help pupils to speak English fluently?

This article opens with an introduction to brief the readers on the focus of the current study. Next, the literature review provides substantial theoretical perspectives and concepts relevant to the study with a detailed review of the past studies conducted in the field of MALL for speaking. At the same time, the literature gaps are identified to shed some light on the significance of this study. This is then followed by the methodology which outlines the research design, instruments, participants, data analysis and the aspects of validity and reliability. The findings of this study are presented and discussed in relation to the reviewed 
literatures and past studies. Finally, the findings are concluded by highlighting possible implications and recommending suggestions for future research.

\section{Literature Review}

The Concept of Mobile-assisted Language Learning (MALL)

Trifonova and Ronchetti (2003) define mobile learning as the application of Information and Technology (IT) assisted by mobile devices to enhance the teaching and learning experience. MALL can also be defined as the use of diverse mobile technologies in language acquisition. Past researchers identified 6 learning theories associated with the employment of mobile technologies in language learning, namely behaviourism, constructivism, situated, collaboration, informal learning and lifelong learning, and support in teaching and learning (Karim et al., 2017; Rahamat et al., 2017; Cakmak, 2019).

Traxler and Kukulska-Hulme (2015) claimed that MALL has been widely advocated in the educational context. The reviews done by past researchers suggest that MALL has been developed into a field in its own right. This resulted in an increase in the number of studies examining the use of various mobile devices both inside and outside of formal language learning, as pointed out by Hashim et al. (2017). Klopfer et al. (2002) reviewed 5 unique educational attributes of mobile devices which add value to MALL:

- Portability: the ability to learn on the move.

- Social interactivity: communication between the users is facilitated.

- Context sensitivity: the provision of real data that is relevant to the learners' location and time.

- $\quad$ Connectivity: getting connected to each other or having a shared network.

- Individuality: the ability to perform independent learning.

In relation to the above attributes, Hashim et al. (2017) stated that technologies, particularly mobile devices such as handphones, iPods, and PDAs, are handheld devices. This makes it easier for the learners to use them as a tool to enhance their language learning. These handheld devices are considered suitable for modern education as they are small and exhibit portability, functionality, ubiquity, utility, and connectivity (Hashim et al., 2017). They provide a richer learning environment for learners by extending the learning environment beyond the classroom setting. This allows learning to take place anywhere at any time so then even learners on the move can improve (Kukulska, 2009). Klimova (2017) claims that the majority of learners nowadays own a mobile phone and about half of them own more than one. This indicates that mobile phones could be considered a potential tool as part of embracing the future of language learning prospects.

\section{Speaking Fluency}

The current study adopts the idea of fluency which relies on the pupils' ability to speak English with facilitation skills (filler, lexical phrases, ellipsis...etc.) and compensation skills (self-correction, rephrasing, or repeating) in order to cope with the ongoing fast communication as opined by Widdowson (1998) and Segaowitz (2000). This refers to "smoothness". Smoothness pertains to the ease of regularity (Housen et al., 2012) with which a speaker can flow when delivering 
spoken content by joining sounds, syllables, words, and phrases together without stammering, stuttering, cluttering, or mumbling.

\section{The Application of MALL and the Learners' Speaking Fluency}

Several studies indicate that the learners' speaking fluency improves when they use the audio and video recording features of a mobile phone to record and review their speaking performance either individually or as part of a class. A study done by Moghaddas and Bashirnezhad (2016) among a group of Iranian higher education learners has proven that the learners' utterance fluency improved when they recorded and listened to their voice recordings. Similarly, a group of Malaysian undergraduate learners in Darmi and Albion's (2017) study reported improved speaking fluency. They were able to identify errors in their speech through the recording. Besides, their classmates' feedback was regarded as helpful as they reviewed the recordings collectively. This is further confirmed by Soto and Zenteno's (2019) study which discovered that there was progress in terms of the phrasing, volume, smoothness, and pace among $317^{\text {th }}$ grade South American learners. They were noticeably putting in the effort to perform better in the upcoming speaking tasks after having their errors identified.

The learners' speaking fluency is further improved as they actively participate in MALL environments. The learners in the work of Darmi and Albion (2017) and the 38 Indonesian learners at Borneo University in Kusmaryani et al.'s (2019) study were discovered to be actively taking part when they use mobile applications for speaking. Likewise, 86 Chinese learners at a civil aviation vocational college involved in Yin's (2019) study actively engage in speaking through the audio and video recording features of a mobile phone. Azlan et al.'s (2019) study indicated that the infusion of the Instagram face-filter interface promoted active participation in the speaking performance among the group of pre-school and primary school pupils in Malaysia. This special feature is also believed to motivate and boost the pupils' interest in continuing their speaking in English. Furthermore, Instagram is reported to be actively used as it has improved the communication skills of ESL adult learners from 42 different countries (Gonulal, 2019). Sherine et al. (2020), on the other hand, found that active speaking tasks among a group of Indian undergraduate engineering learners through the use of WhatsApp improved their fluency, coherence, lexical resource, grammatical range and accuracy, and pronunciation. In terms of motivation, mobile apps have been viewed as a great tool for maintaining the learners' interest and improving their confidence to speak the target language. In relation to this, the use of the "Speaking English 60 Junior" app installed with Automatic Speech Recognition (ASR) feature immediately demonstrated the consequence of the speech input with a virtual character via ASR. The learners in the work of Ahn and Lee (2016) showed great interest in it for speaking. Furthermore, the teachers in Abugohar et al. (2019) study found mobile apps such as 'Talking Tom', 'Virtual Speaking Buddy', 'Voki' and 'Talking Angela' as being helpful in motivating learners to speak English confidently. This mirrors the impact of using the "English Daily" mobile app among learners in Tonekaboni's (2019) study.

A study conducted by Ahn and Lee (2016) examining a group of Korean middleschool learners reflected that the use of the "Speaking English 60 Junior" app 
installed with the Automatic Speech Recognition (ASR) feature has facilitated their speaking fluency achievement by contextualising the language use in specific social situations. Supporting this, contextual learning experiences positively affected the 209 Arabian undergraduate learners at the King Saud University who were involved in the survey conducted by Almarshadi et al. (2019). The survey revealed that the use of the smartphone's built-in features such as the dictionary, mobile apps, and SNSs such as WhatsApp and e-mail improved the learners' pronunciation, grammar accuracy and oral comprehension. The significance of contextual learning is equally illustrated in Kusmaryani et al.'s (2019) study as the learners explored materials outside of the classroom. Roach et al. (2018) proclaimed that authentic learning materials will substantiate contextual learning as the learners integrate their previous experience into their current realities. Mobile apps are believed to provide authentic learning opportunities for learners, allowing them to obtain a better understanding as they get to apply speaking in real-world conversations (Ahn \& Lee, 2016; Almarshadi et al., 2019; Kusmaryani et al., 2019). In addition, 49 Arabian teachers from higher education institutes in the work of Abugohar et al. (2019) proclaimed that mobile apps are believed to cater to shy and anxious learners as they create a less stressful teaching and learning environment.

Studies done by Moghaddas and Bashirnezhad (2016), Darmi and Albion (2017), Azlan et al. (2019) and Kusmaryani et al. (2019) indicate that MALL allows learners to learn in collaboration as opined by Vygotsky (1978) in his social constructivism theory. Learners are regarded as speaking better as they get their errors corrected by both their teacher and peers. Nevertheless, collaborative speaking tasks in WhatsApp have significantly reduced the fear of receiving feedback and taking language tests among 9 Syrian graduates at Aleppo University, thus improving their fluency.

MALL has allowed learners to get access to learning without place and time constraints, provided that the mobile devices can be explored 'anywhere' at 'anytime'. An empirical analysis done by Wan (2019) among colleges in China has proven the "English Fluent" app as being beneficial for the learners. They were provided with rich learning content useful for speaking practices regardless of the place and time. Similar results were reported by Tonekaboni's (2019) study which involved the use of the "English Daily" app among a group of Iranian elementary learners aged $14-17$ years old at the Kish Language Institute. A recent study done by Wang and Hsu (2020) using the "English Messenger" app among a group of Taiwanese undergraduate and graduate learners at the National Kaohsiung University reported a significant improvement in using conversational English for business among them. The mobility of mobile devices has further promoted autonomous learning. Lutfi's (2020) findings implied that 30 tertiary level students in Yogyakarta were able to use the 'Quizlet' app to carry out speaking independently. Interestingly, a recent survey among 41 Indian learners at Sri Ramakrishna Institute of Technology (SRIT) by Nanjundan et al. (2020) indicated that such apps could fulfil the self-study concept. 
To conclude, it has been made crystal clear that the use of multiple mobile devices in various MALL contexts worldwide has positively contributed towards the development of speaking fluency among the studied learners. However, most of the studies were conducted among tertiary level learners and only one among the reviewed studies was done at the primary level (Azlan et al., 2019). This study aspires to fill in the existing literature gap by exploring how the use of the ChatterPix Kids mobile app could help a group of Malaysian primary ESL pupils in developing their speaking fluency.

\section{ChatterPix Kids Mobile App}

The ChatterPix Kids is a free downloadable app for mobile devices that was created by Duck Duck Moose, Inc, a part of the Khan Academy family. The family creates educational mobile apps for adults as well as young learners. The app can be downloaded on any mobile device including smartphones, iPads and tablets through either the Google Play Store or the Apple Store. Marciano (2018) views ChatterPix Kids as a fun and interesting mobile app that allows young children to snap a photo, record their voice and make images "talk". The recording can later be replayed, edited, and saved to their device's gallery. The researchers believe that ChatterPix Kids can be a potential tool to help the ESL learners develop their speaking fluency. However, there has only been one study done by Marciano (2018) using ChatterPix Kids as a tool for reading aloud and reducing stress among American teachers and students. This study intends to highlight the potential of the ChatterPix Kids mobile app in helping primary ESL pupils to develop their speaking fluency.

\section{Methodology \\ Research Design}

The current study employed the case study method under the qualitative approach. The data collected in this study was based on the pupils' authentic experiences of interacting with the ChatterPix Kids mobile app for speaking activities and their parents' feedback based on their observations. The pupils involved in this study experienced using the app for speaking practice during the $\mathrm{MCO}$ for 12 speaking lessons. They used the app to capture images related to the speaking tasks given and recorded their voice to create "talking" avatars. Upon recording their voices based on the topics given from the modules stipulated in the CEFR Get Smart Plus 3 Student's Book, which was the main textbook, the recordings were shared in Google Classroom. These were reviewed by both the teacher and their classmates. Figure 1.0 below shows snapshots of the voice recordings done across the 12 consecutive speaking lessons. 


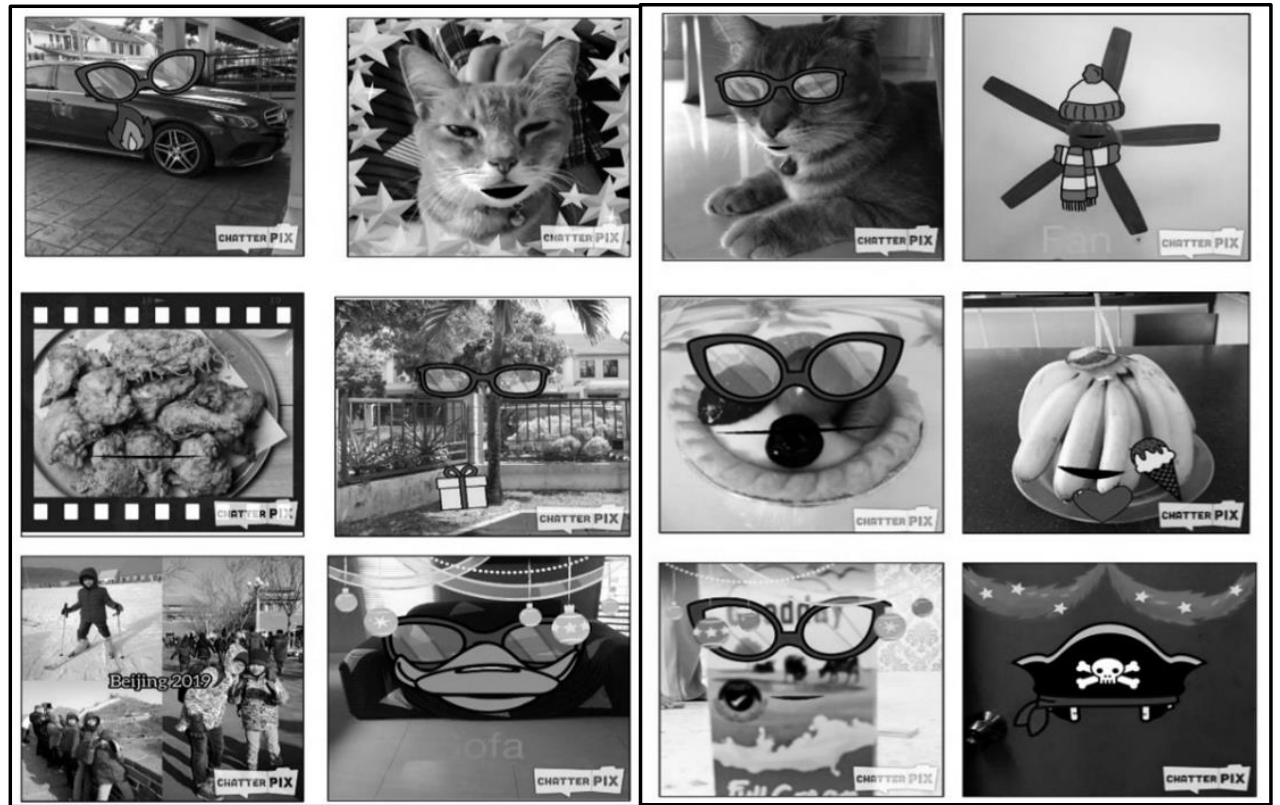

Figure 1.0 Snapshots of the voice recordings done by the pupils using ChatterPix Kids

Figure 1.0 above illustrates that the pupils used the app to snap pictures of living and non-living things in their surroundings before making them into "talking" avatars through a voice over. As the pupils continued doing this as part of their learning, their speaking fluency progressed.

\section{Research Instruments}

It is important to note that qualitative research does not restrict the views of the participants. At the same time, Creswell (2014) claimed that the researcher never used someone else's instrument. Instead, the researchers' "record information on self-designed protocols that help in organising information reported by participants to each question" (Creswell, 2014, p. 227). In this qualitative case study, the data was obtained through one-on-one semi-structured interviews and a focus group discussion with 5 purposively selected Year 3 primary ESL pupils. This was in addition to collecting their parents' feedback through open-ended questionnaire. The findings obtained from all three instruments were triangulated in order to enhance the credibility of the findings.

\section{Semi-structured interviews (SSI)}

The semi-structured interviews were conducted on an individual basis with the pupils to discover their experience of using the ChatterPix Kids mobile app for speaking practice. Additionally, it was to gather insights on how to use the app as a speaking tool that could help them to develop their speaking fluency. The interview protocol was self-designed by the researcher (see Appendix A). The interview questions were also tested on the participants' classmates and a few questions were made simpler to suit the participants' proficiency level. Given that the participants were intermediate users of English, several questions were translated into their mother tongue and they were validated by the school's Head of Language Panel. Semi-structured interviews allowed for a degree of flexibility to let the researcher probe and obtain answers on how the pupils' speaking fluency could have been developed using the ChatterPix Kids mobile app. This was done by posing more enhanced questions than the initially drafted ones. 


\section{Focus Group (FG)}

The findings obtained from the focus group are believed to further emphasise the pupils' responses that were obtained through the semi-structured interviews. The interviews were on the use of the ChatterPix Kids mobile app and how it may have helped to develop their speaking fluency. The focus group discussion was carried out using the researcher-made discussion protocol (see Appendix B) as guidance. During the focus group, the pupils were asked to practice turn-taking so then each of them would have an equal opportunity to respond. Several questions were translated into the pupils' mother tongue and they were validated by the school's Head of Language Panel. The focus group discussion was recorded to avoid overlooking or losing any of the information.

\section{Open-ended Questionnaire (OEQ)}

In this study, open-ended questions (see Appendix C) were used as a means of collecting personal feedback from the parents of the pupils involved in the study. Feedback from the pupils' parents was essential in this study as the parents had closely observed their children's activities when using the ChatterPix Kids mobile app as a tool for speaking practice conducted during the remote learning due to MCO. The open-ended questions were self-designed by the researcher by adapting the semi-structured interview and focus-group questions conducted among the pupils.

\section{Research Participants}

The participants of this study consisted of 5 purposively selected Year 3 pupils who had experience of using the ChatterPix Kids mobile app as a tool for speaking practices conducted during the MCO. They had developed fluency in their speech, and their parents had closely witnessed these events. Prior to conducting the study, both the pupils' and parents' consent were obtained through written consent forms (see Appendix D - H). The pupils were from an urban national primary school in Selangor state. Pseudonyms were given to the pupils (P1, P2, P3, P4 and P5) and the parents (Q1, Q2, Q3, Q4 and Q5) to maintain their confidentiality. These pseudonyms were used throughout the discussion. The 5 Year 3 pupils who were purposively chosen for this study had poor fluency when speaking English and they scored in the relatively lower bands in the mid-term CEFR classroom-based speaking assessment. However, an improvement in their fluency was visible as they started practicing speaking alongside the use of the ChatterPix Kids mobile app. They were therefore recruited as participants due to their potential to provide substantial insights. Their parents were also included as participants to obtain their feedback on the effect of using the ChatterPix Kids mobile app on their children's English-speaking fluency.

\section{Data Analysis}

The data was collected through semi-structured interviews, a focus group and an open-ended questionnaire that were all transcribed in verbatim. The transcripts were then analysed using the 6-phased thematic analysis proposed by Braun and Clarke (2006) in order to understand how the use of ChatterPix Kids could have helped the pupils develop their speaking fluency. First and foremost, the transcriptions were read multiple times to become familiarised with the participants' responses. During this process, their theoretical and reflective 
thoughts were penned down, and potential codes were jot down based on the reviewed literature. Next, the initial codes were manually assigned to the data by highlighting words, phrases and sentences that appear important and interesting in relation to answering the research question. For example, responses such as "can speak English more" and "can speak English always" were highlighted as they were regarded as significant when forming the themes. In the third phase, the identified codes were sorted into relevant themes. To come up with the themes, the listed codes were linked to their associated extracts and then collated into groups. For instance, the codes mentioned above were collated into one single theme, 'more engagement in speaking task'. The generated themes were then linked to the concepts involved in the respective theories and concepts referred to in this study. For instance, 'active learning' and 'portability'. The themes were then reviewed and refined. The identified extracts were checked to see whether they support or contradict the themes suggested. Nevertheless, any overlapping themes were either split or the codes were shifted into the existing themes where they fit better. I the fifth phase, the identified themes were linked to the existing literature and the previous studies were reviewed as a basis for forming the theoretical and conceptual ideas in this study. At this point, the attributes of the mobile devices coined by Klopfer et al. (2002) appeared to complement the identified concepts. Finally, the discovered themes were reported in detail to adequately answer the research question. They were further justified by referring to the relevant extracts from the participants' responses, reviewed literature, and past studies.

\section{Validity and Reliability}

Guba and Lincoln (1989) argued that the "trustworthiness" of qualitative inquiry could be established by addressing the following characteristics of a research, which are credibility, transferability, dependability, and confirmability. In this study, the credibility of the data was ensured by having the Head of the English Panel in the school in which the study was conducted perform member-checking on the instruments that were prepared by the researcher before the data collection process. In addition, the data was collected using 3 different instruments such as semi-structured interviews, a focus group, and an open-ended questionnaire for the purpose of data triangulation. This yields more rigorous findings and provides a better understanding of the findings from different perspectives. The transferability of the study's findings was ensured by providing a detailed account of the context of the study and the participants involved. In terms of the increasing dependability, the researcher sought a colleague's assistance when performing the audit trail on the data collected in this study. Finally, data confirmability was achieved by allowing the participants to read their transcriptions to ensure that their responses were reported without being fabricated. The participants' identities remained confidential throughout the data reporting.

\section{Findings and Discussion}

The findings of this study are presented by thematically analysing the responses obtained from the pupils through the semi-structured interviews (SSI) and focus group (FG) as well as their parents' feedback obtained through the open-ended 
questionnaire (OEQ). The data obtained from all 3 instruments was triangulated to yield credible themes.

How does the use of the ChatterPix Kids mobile app help the pupils to speak fluently?

The findings obtained in this study suggest that the use of the ChatterPix Kids mobile app has helped the primary ESL pupils develop their speaking fluency. Pupils who have been hesitating, stammering, stuttering, and facing difficulties to express themselves fluently in English were discovered to have smoothness when delivering oral messages after using ChatterPix Kids as a tool for speaking practice. The analysis of the findings resulted in 7 themes as shown in Figure 2.0 below.

\begin{tabular}{|l|l|}
\hline Themes & \begin{tabular}{l} 
Authentic tasks in meaningful contexts \\
More engagement in speaking tasks \\
\hline Application of prior knowledge to current situations \\
\hline
\end{tabular} \\
\hline Self-reflection and error correction \\
\hline Sexibility in learning \\
\hline
\end{tabular}

Figure 2.0 Themes raised in the analysis

The themes illustrated in Figure 2.0 above suggest how ChatterPix Kids could help the pupils develop their speaking fluency. The themes were further discussed with close reference to the relevant literature and past studies.

\section{Authentic tasks in meaningful contexts}

Roach et al. (2018) stated that authentic learning experiences could enable the pupils to process new information or knowledge in such a way that it makes sense to them in their frame of reference. Parallel to this, the pupils involved in this study comprehended the words or phrases used to describe both living and nonliving objects around them. The ability to practice speaking using authentic materials in meaningful contexts via ChatterPix Kids is made apparent through the participants' responses.

"I make my TV talk, chair and my cat. I also make the car to talk. That day I take a picture of fruits and make it talk." (P1, SSI)

"I think ChatterPix can help me to speak better in English because I can

let the things I like to talk in my voice." (P2, FG)

"He made our cat to speak in his voice and he also made a birthday wish for his brother by making his brother's picture talk." (Q1, OEQ)

The responses above clearly indicate that pupils were able to practice speaking and were working towards developing their speaking fluency by exploiting the various authentic materials available in their immediate surroundings. This 
echoes the findings of the previous studies (Ahn \& Lee, 2016; Abugohar et al., 2019; Almarshadi et al., 2019; Gonulal, 2019; Kusmaryani et al., 2019; Sherine et al., 2020). The mobile app being 'context sensitive' (Klopfer et al., 2002) is seen of as helpful when making authentic learning possible.

\section{More engagement in the speaking tasks}

Constructivists believe that learners construct meaning only through active engagement with the real-world tasks being performed (Piaget, 1968). Similarly, the pupils in this study who were previously shy, anxious, less motivated, and timid to speak in English during the classroom presentations started developing confidence and an interest in the speaking tasks. This was because they could use the ChatterPix Kids to practice speaking in any situation, be it inside or outside the house because a smartphone is portable (Klopfer et al., 2002). The use of the app increased the pupils' engagement and widened the pupils' speaking opportunities. They proclaimed the following:

"The app lets me to talk more in English at home and when I go out of my house. I can take picture of anything I like and speak in English to make the picture talk." (P3, SSI)

"(...) the app makes me to talk more English at home. I can talk in

English when I play with the app always." (P1, FG)

Supporting this, one of the parents' responded:

"The app helps him to express himself in English as he always uses Malay at home." (Q4, OEQ)

The infusion of ChatterPix Kids has profoundly increased the pupils' engagement with the speaking tasks. As the pupils become more engaged, their speaking fluency eventually develops as indicated in the other studies done in MALL environments (Darmi \& Albion, 2017; Azlan et al., 2019; Gonulal, 2019; Kusmaryani et al., 2019; Sherine et al., 2020; Yin, 2019).

\section{Application of prior knowledge to current situations}

Piaget (1968) argues that knowledge assimilation takes place as the learners incorporate new experiences into their old experiences. In other words, linking their prior knowledge to their current knowledge or vice versa. In this study, pupils were discovered to use the words, phrases, and sentences taught to them in both face-to-face and virtual speaking lessons in daily situations that they were currently facing. Along this process, pupils find a 'fit' between their prior knowledge and current knowledge thus helping them to orally produce smoother speech with less hesitations and distortions as they tend to have reduced fillers such as "umm", "aah", and "hmm" as they try searching for appropriate words to be included in their speech. Supporting this, the pupils confessed the following:

"I can speak better because I use the sentences teacher teach me in class." (P1, SSI)

"(...) The app allows me to use the sentences I have learned in English. I can practice saying the sentences more." (P5, FG)

In addition, one of the pupils noted that he was able to remember the words better as he uses them in his speech. He proclaimed that: "I can practice words and sentences teacher has teach me in class. I can remember better also." (P3, SSI) 
The pupils' claims are further supported by one of the parents' confessions: "She is braver to speak in English freely because she can use the correct words." (Q2, OEQ)

As asserted by Perkins and Salomon (1988), it is important for learners to apply the knowledge learned in one situation to other situations as it will improve their comprehension. The pupils in this study were believed to gain a better understanding of the use of the words learned before, enabling them to convey their oral messages with ease and clarity. This echoes Darmi and Albion's (2019) findings.

\section{Self-reflection and error correction}

Next, the pupils in this study could have developed their speaking fluency as they could perform 'knowledge accommodation' to modify their existing knowledge when it does not fit the current situation (Piaget, 1968). As a matter of fact, the ChatterPix Kids mobile app has allowed pupils to identify mistakes that cause disfluency in speech such as long pauses, the wrong usage of words and too many fillers. They performed self-corrections. The feature of the ChatterPix Kids mobile app that allows pupils to re-record, play, pause, stop, and backtrack while listening to their voice recordings provides ample opportunities for them to meticulously listen and rectify their mistakes in terms of speaking fluency. Similar results have been seen in a few studies (Moghaddas \& Bashirnezhad, 2016; Darmi \& Albion, 2017; Soto \& Zenteno, 2019) in which learners put in the effort to perform better in the speaking tasks as they recorded and reviewed their speaking performance. To substantiate this, the pupils were asked about what they normally do if they think that their voice recordings are not fluent. They mentioned the following:

"I will practice, and I will do the recording again. I will read the

sentences and remember then I will record my voice again." (P1, SSI)

"I will record again until I get correct." (P4, SSI)

Supporting this, one of the parents' confessed:

"My child likes to replay the recordings again and again to check if he has spoken correctly." (Q1, OEQ)

As the pupils noticed errors in their recorded speech, they immediately recorded their speech again to do better. Some of the pupils' responses depict that they have applied various strategies such as reading the sentences repeatedly, memorising words, and self-rehearsing before recording their voice. This supports Nanjundan et al.'s (2020) claim that MALL could promote the self-study concept and provide self-learning opportunities.

\section{Flexibility in learning}

The use of ChatterPix Kids is regarded as flexible. This is because the pupils were able to use the app for speaking practices in an extended learning environment beyond their classroom context (Kukulska, 2009). At this point, the portability and individuality features of the mobile devices (Klopfer et al., 2002) allow the personalised learning to take place anywhere and at any time. The pupils proclaimed that: 
"I can speak English always by using the app because I can use it anytime at different places. Like in my house, in my bedroom, at my garden, and in my father's car." (P1, SSI)

"Yes, I can speak English more because the app is fun and interesting.

I make sure I speak only in English when I use the app." (P5, FG)

Parents' feedbacks add better insights on how ChatterPix Kids offers convenient and flexible learning approaches to pupils.

"Yes, she can use the app anytime she wants. She will try speaking

English using different things she finds at home." (Q2, OEQ)

The excerpts above support the findings of Tonekaboni (2019), Wan (2019) and Wang and Hsu (2020) in which the learners involved in their study have practiced speaking flexibly using mobile apps such as "English Daily", "Fluent App", and "English Messenger". Nevertheless, the pupils in this study were discovered to be autonomous learners as they used ChatterPix Kids to carry out speaking activities on their own without being dependent on their teacher (Lutfi, 2020).

\section{Reduced fear and anxiety}

Apart from that, the pupils' responses depict that they have reduced fear and anxiety when speaking in English if they use ChatterPix Kids. Pupils who were initially shy, timid, and anxious about participating in speaking activities during the speaking lessons in the classroom were detected to have improved self confidence when speaking the target language with the help of ChatterPix Kids. Moreover, the pupils proclaimed that the app allowed them to practice speaking in a fun, less stressful, and playful manner. This lowered their anxiety when uttering words in the target language. Accordingly, the participants responded as follows:

"Not shy because I feel like playing the app is so nice and if speak wrong can play again." (P3, SSI)

"Yes, I can speak English more because the app is fun and interesting.

I make sure I speak only in English when I use the app." (P5, FG)

"She is braver to speak in English freely." (Q2, OEQ)

However, some pupils contended that:

"Sometimes I feel shy if I talk in front of my mother...but if I talk in my room then I am not so shy." (P2, SSI)

"I feel shy sometimes, but I also feel happy when they say the recording is good." (P5, SSI)

The responses above suggest that ChatterPix Kids has the potential to lessen the pupils' fear and anxiety, thus allowing them to speak the target language more fluently. This echoes the findings of several studies that have proven that mobile apps are a great motivational tool for learners to use to speak confidently (Ahn \& Lee, 2016; Abugohar et al., 2019; Tonekaboni, 2019). Furthermore, it supports Azlan et al.'s (2019) and Shamsi et al.'s (2019) claims that the learners' speaking performance improved in less stressful environments. However, P2's (SSI) and P5's (SSI) responses indicate that there is a need to further investigate how the pupils' confidence when speaking can be sustained while speaking in front of others at the same time as in the absence of ChatterPix Kids. 


\section{Scaffolding from More Knowledgeable Others (MKO)}

Throughout their speaking practices, the pupils were scaffolded by MKOs in their immediate surroundings. All of the pupils contended that they sought assistance from their teacher and family members such as their mother, father, sister, and brother. This was in order to listen to their recorded speech and to correct their errors. The feedback provided by their family members is believed to be useful and helpful when seeking to improve the pupils' speech as well as the development of their speaking fluency. On this note, Vygotsky's (1978) claim that cognitive development is a product of social interaction is supported. The pupils' enhanced understanding, especially on the use of appropriate words to speak, could only be possible with the help of people around them as indicated by this study. Substantiating this, the pupils stated that:

"(...) I ask my brother to check for me." (P1, SSI)

"Yes, I share with my mum. I feel nice because my mum can tell me what is wrong." (P5, FG)

At this point, it could be concluded that the concept of Zone of Proximal Development (ZPD) as proposed by Vygotsky (1978) is applied, and that it complements the findings of the previous studies (Moghaddas \& Bashirnezhad, 2016; Kusmaryani et al., 2019; Shamsi et al., 2019). These have proven that speaking fluency among the learners is a product of collaboration and cooperation among their peers. The scaffolding provided by MKO boosts the pupils' performance in their speaking tasks (Vygotsky, 1978). For example, P5 stated that he felt 'nice' when his mother corrected his mistakes. Nevertheless, the aspects of social interactivity and connectivity (Klopfer et al., 2002) are proven to be helpful as pupils can share their recordings with others for both validation and entertainment purposes.

\section{Conclusion}

The findings of this study suggest that ChatterPix Kids could be one among the language learning mobile apps that are regarded as useful and helpful when developing the primary ESL pupils' speaking fluency. The participants' responses depict that the continuous usage of the app has resulted in smoothness in the pupils' speech while speaking the target language. They were observed as being able to deliver oral messages in English with ease and confidence, which is distinct from how they were prior to using the app. Alongside that, their speech appears fluent with reduced speech fillers such as "umm", "aah", and "hmm", in addition to reduced self-correction, rephrasing, and repeating. Based on the findings, it could be concluded that the primary ESL pupils' speaking fluency has been developed by using ChatterPix Kids as the app allows room for speaking in authentic situations, provides more engagement with the target language, allows for the application of prior knowledge to current situations, fosters autonomy through self-reflection and error correction, provides flexibility in learning, allows speaking with reduced fear and anxiety, and encourages learning through scaffolding by more knowledgeable others (MKO). These themes are believed to support the concepts propagated by the constructivism theory developed by both Piaget (1968) and Vygotsky (1978) as well as validating the attributes of mobile 
devices: portability, social interactivity, context sensitivity, connectivity, and individuality (Klopfer et al., 2002).

\section{Implications}

The findings of this study imply that the integration of mobile phones as a part of technology application in Malaysian mainstream schooling could be considered through a proper review and planning of the educational policies by both policy makers and curriculum developers. An instructional toolkit or module could be prepared to highlight the efficacies of the ChatterPix Kids mobile app in ESL learning. Courses, workshops and training could be conducted for the teachers, especially those teaching in primary schools, in order to buff up their skills and enhance their knowledge of integrating MALL. Teachers need to be knowledgeable, skilful, and approachable when embracing MALL in the process of infusing technology into their instructional practices for the current generation who are regarded as digital natives. As implied by the findings, ESL learners, especially primary school pupils, may use various English learning mobile apps that are readily available for both Google Android and Apple iOS operating systems. This is in order to enrich their language learning process. Meanwhile, parents are encouraged to be supportive towards the use of mobile phones for their children's learning by providing the necessary guidance and at the same time, by constantly monitoring their learning activities.

\section{Limitations and Recommendations for Future Research}

The current study was conducted by exploring the views of 5 purposively selected primary ESL pupils and their parents regarding the use of the ChatterPix Kids mobile app as a tool for speaking practice. The findings are subjected to the context of the study and may not be generalised. Researchers are recommended to explore how ChatterPix Kids can be used to develop other language skills such as listening, reading, and writing. Since the current study was done among urban school pupils, similar studies ought to be conducted in sub-urban and rural schools to see if they complement or contradict the findings of the current study. Finally, the findings of the current study imply that there is a need to investigate on how the pupils' confidence could be sustained while speaking in public in the absence of the app.

\section{References}

Abugohar, M. A., Rashid, R. A., \& Yunus, K. (2019). Smartphone Applications as a Teaching Technique for Enhancing Tertiary Learners' Speaking Skills: Perceptions and Practices. International Journal of Emerging Technologies in Learning (iJET), 7492. http://doi.org/10.3991/ijet.v14i09.10375

Azlan, N. A. B., Zakaria, S. B., \& Yunus, M. M. (2019). Integrative task-based learning: Developing speaking skill and increase motivation via Instagram. International Journal of Academic Research in Business and Social Sciences, 9(1), 620-636. http:/ / doi.org/10.6007/IJARBSS/v9-i1/5463

Braun, V., \& Clarke, V. (2006). Using thematic analysis in psychology. Qualitative research in psychology, 3(2), 77-101. http://doi.org/10.1191/1478088706qp063oa

Çakmak, F. (2019). Mobile Learning and Mobile Assisted Language Learning in Focus. Language and Technology, 30-48. 
Creswell, J. W. (2014). Research Design; Qualitative, Quantitative and Mixed Methods Approaches. Thousand Oaks, CA: Sage.

Darmi, R., \& Albion, P. (2017). Enhancing oral communication skills using mobile phones among undergraduate English language learners in Malaysia. In Mobile Learning in Higher Education in the Asia-Pacific Region (pp. 297-314). Springer, Singapore. http://doi.org/10.1007/978-981-10-4944-6_15

Gonulal, T. (2019). The Use of Instagram as a Mobile-Assisted Language Learning Tool. Contemporary Educational Technology, 10(3), 309-323. http://doi.org/10.30935/cet.590108

Guba, E. G., \& Lincoln, Y. (1989). Fourth generation evaluation. Newbury Park: CA: Sage.

Hashim, H., Yunus, M. M., \& Embi, M. A. (2016). Pre-University English as Second Language (ESL) learners' attitude towards mobile learning. Creative Education, 7(08), 1147.

Hashim, H., Yunus, M. M., Embi, M. A., \& Ozir, N. A. M. (2017). Mobile-assisted language learning (MALL) for ESL learners: A review of affordances and constraints. Sains Humanika, 9(1-5). http://doi.org/10.11113/sh.v9n1-5.1175

Ismail, I., Azizan, S. N., \& Gunasegaran, T. (2019). The Use of SMS in Promoting Inquisitiveness among Distance Learners. Malaysian Journal of Distance Education, 21(1).

Klimova, B. (2018). Mobile phones and/or smartphones and their apps for teaching English as a foreign language. Education and Information Technologies, 23(3), 10911099.

Kloper, E., Squire, K., \& Jenkins, H. (2002). Environmental Detectives: PDAs as a Window Into A Virtual Simulated World. Proceedings for IEEE International Workshop on Wireless and Mobile Technologies in Education, 95-98.

Kukulska-Hulme, A. (2009). Will mobile learning change language learning? ReCALL, 21(2), 157-165.

Kusmaryani, W., Musthafa, B., \& Purnawarman, P. (2019). The influence of mobile applications on students' speaking skill and critical thinking in English language learning. Journal of Physics: Conference Series, 1193, 1-6. http://doi.org/10.1088/1742-6596/1193/1/012008

Leong, L.-M., \& Ahmadi, S.M. (2017). An Analysis of Factors Influencing Learners' English Speaking Skill. International Journal of Research in English Education, 34-41.

Malaysian Communications and Multimedia Commission (MCMC). (2017). Internet Users Survey 2017. Selangor: Malaysian Communications and Multimedia Commission.

Malaysian Ministry of Education. (2013 - k2025). Malaysian Education Blueprint. Kuala Lumpur: Kementerian Pendidikan Malaysia.

Moghaddas, B., \& Bashirnezhad, H. (2016). The Pedagogical Applications of MobileAssisted Language Learning (MALL) in Improving the Iranian EFL Learners' Oral Performance. International Journal of Applied Linguistics and Translation, 2(1), 8-14. http:// doi.org/10.11648/j.ijalt.20160201.12

Lutfi. (2020). The Integration of MALL to Enhance Students Speaking Skill: An Autonomous Learning Model. Journal of Foreign Language Teaching and Learning, 5(1), 1-19.

Nanjundan, V., Senthilkumar, S., Jayasudha, T., \& Sankar,G. (2020). Adoption of Mobile Learning to Enhance LSRW Skills For Learners of English as Second Language. Journal of Xi'an University of Architecture \& Technology, 2596-2610.

Nijat, N., Atifnigar, H., Chandran, K., Selvan, S. L. T., \& Subramonie, V. (2019). Psychological Factors that Affect English Speaking Performance among Malaysian Primary School Pupils. American International Journal of Education and Linguistics Research, 2(2), 55-68. 
Paneerselvam, A., \& Mohamad, M. (2019). Learners' Challenges and English Educators' Approaches in Teaching Speaking Skills in an ESL Classroom: A Literature Review. Creative Education, 10(13), 3299-3305. http://doi.org/10.4236/ce.2019.1013253

Piaget, J. (1968). Six Psychological Studies. New York: Vintage Books.

Precintha, R. A., James, P. P., Yong, K. L., \& Yunus, M. M. (2019). Hear me out! Digital storytelling to enhance speaking skills. Int. J. Acad. Res. Bus. Soc. Sci, 9, 190202. http:// doi.org/10.6007/IJARBSS/v9-i2/5533

Rahamat, R. B., Shah, P. M., Din, R. B., \& Abd Aziz, J. B. (2017). Students'readiness And Perceptions Towards Using Mobile Technologies for Learning The English Language Literature Component. The English Teacher, 16.

Rao, P. S. (2019). The Role of English as a Global Language. Research Journal of English, 4(1):65-79.

Roach, K., Tilley, E., \& Mitchell, J. (2018). How authentic does authentic learning have to be?. Higher Education Pedagogies, 3(1), 495-509.

Samat, N. A. A., Muthu, S., \& Yunus, M. M. (2019). Dubslinguistic Enhancing English Communication Skills among Malaysian Primary School Pupils. Creative Education, 10(01), 48.

Shamsi, A. F., Altaha, S., \& Gilanlioglu, I. (2019). The Role of M-Learning in Decreasing Speaking Anxiety for EFL Learners. Online Submission, 2(1), 276-282. http://doi.org/10.32996/ijllt.2019.2.1.34

Sherine, A., \& Seshagiri, A. V. S. (2020). Impact of WhatsApp Interaction on Improving L2 Speaking Skills. International Journal of Emerging Technologies in Learning (iJET), 15(3), 250-259. http:// doi.org/10.3991/ijet.v15i03.11534

Soto, C. P., \& Zenteno, C. C. (2019). Smartphone screen recording apps: an effective tool to enhance fluency in the English language. Colombian Applied Linguistics Journal, 21(2). http:// doi.org/10.14483/22487085.14202

Tonekaboni, A. M. (2019). Effects of Mobile Assisted Language Learning (MALL) on Speaking Proficiency (A case of Learn English Daily Mobile App). In 2nd International Conference on Advanced Research in Humanities and Art (pp. 1-13). Venice, Italy.

Vygotsky, L. S. (1978). Mind in Society. Cambridge: MA: MIT Press. 


\section{APPENDIX A \\ SEMI-STRUCTURED INTERVIEW \\ PROTOCOL}

\begin{tabular}{ll}
\hline No & Questions \\
\hline 1 & Do you like to use ChatterPix Kids mobile app? \\
2 & Could you explain why you say so? \\
3 & What else do you think you can do with this app? \\
4 & Do you think the app is interesting? Why? \\
5 & What are the things that you have made talking using the app? \\
6 & How do you normally select the things? \\
7 & How do you feel when you record your voice using the app? \\
8 & What do you do if your recording is not good enough? \\
9 & What do you like about the app? \\
10 & Do you think you can use the app on your own? \\
11 & Does the app allow you to practice speaking English more? Why you say so? \\
12 & Do you send the recording to others? \\
13 & What do you feel when you do that? \\
14 & Would you recommend this app to others? Why? \\
\hline
\end{tabular}

\section{APPENDIX B \\ FOCUS-GROUP DISCUSSION PROTOCOL}

\begin{tabular}{l}
\hline Questions \\
\hline Good morning, everyone. Thank you for participating in this discussion. In this \\
discussion, you will be asked a few questions based on your experiences of using the \\
ChatterPix Kids mobile app for your speaking practices during the Movement Control \\
Order (MCO). Your responses will be very helpful for my research and please note \\
that your identities will be kept confidential. Before we start the discussion, let me ask \\
if you agree to participate in this discussion. \\
\hline Do you think the app allows you to speak in English more often? Explain your answer. \\
\hline Do you think you can speak better when using the app? Why? \\
\hline How do you feel speaking using the app? \\
\hline Does the app allow you identify your mistakes? \\
\hline Do you think the app is important for you? Why? \\
\hline Is the app easy to be used? Why? \\
\hline Do you think the app is useful? Explain your answer. \\
\hline Where do you use the app at? \\
\hline Do you share the recordings to others? \\
\hline How would you use the app in future?
\end{tabular}




\section{APPENDIX C \\ OPEN-ENDED QUESTIONNAIRE FOR PARENTS}

\begin{tabular}{ll}
\hline No & Questions \\
\hline 1 & $\begin{array}{l}\text { Do you think the ChatterPix Kids mobile app is helpful for your child's speaking } \\
\text { tasks? }\end{array}$ \\
\hline 2 & $\begin{array}{l}\text { In your opinion, how do you think the ChatterPix Kids mobile app could have } \\
\text { helped your child in gaining speaking fluency? }\end{array}$ \\
\hline 3 & $\begin{array}{l}\text { Do you think your child has more opportunities to speak in English at home } \\
\text { with the use of the app? If yes, why? }\end{array}$ \\
\hline 4 & $\begin{array}{l}\text { Share an interesting event(s) that has taken place while your child uses the app } \\
\text { for speaking. }\end{array}$ \\
\hline 5 & $\begin{array}{l}\text { Is there any noticeable difference in your child in terms of speaking English } \\
\text { before and after using the app? Please elaborate your answer. }\end{array}$ \\
\hline 6 & $\begin{array}{l}\text { How do you think the app could have motivated your child to participate in } \\
\text { English speaking tasks? }\end{array}$ \\
\hline 7 & $\begin{array}{l}\text { How do you think the app could have made your child to stay connected with } \\
\text { his/her surroundings? }\end{array}$ \\
\hline 8 & Do you think the app is easy to be handled by your child? Please explain. \\
\hline 10 & $\begin{array}{l}\text { Do you recommend your child to continue using this app for speaking? If yes, } \\
\text { why? }\end{array}$ \\
\hline
\end{tabular}

http://ijlter.org/index.php/ijlter 
APPENDIX D

PARTICIPANTS' CONSENT LETTERS

(PUPILS AND PARENTS)

Thirumangai A/P Rajendran

Pelajar Sarjana Pendidikan (TESL)

Fakulti Pendidikan

Universiti Kebangsaan Malaysia,

43600 Bangi, Selangor.

Tuan/Puan,

KEBENARAN IBU BAPA/PENJAGA UNTUK MENYERTAI DAN MEMBENARKAN ANAK JAGAAN MENYERTAI KAJIAN PENYELIDIKAN SARJANA

Perkara di atas adalah dirujuk. Saya Thirumangai A/P Rajendran, ingin memohon kebenaran kepada pihak tuan/puan agar memberi kebenaran kepada saya untuk menjalankan kajian tindakan terhadap tuan/puan dan anak jagaan tuan/puan.

2. Tajuk kajian saya ialah "EXPLORING THE OUTCOMES OF USING CHATTERPIXKIDS MOBILE APP ON ESL PUPILS' SPEAKING FLUENCY, MOTIVATION, AND ATTITUDES". Sehubungan dengan itu, tuan/puan dan anak jagaan tuan/puan telah terpilih untuk menjadi peserta kajian ini.

3. Saya memohon kebenaran tuan/puan dan anak jagaan tuan/puan untuk dipilih menjad peserta kajian penyelidikan Sarjana saya. Segala maklumat peserta kajian akan dirahsiakan mengikut kod etika penyelidikan.

4. Oleh yang demikian, saya amat berharap pihak tuan/puan membenarkan saya menjalankan kajian ini terhadap anak jagaan tuan/puan.

Kerjasama dan perhatian daripada pihak tuan/puan, saya dahulukan dengan ucapan terima kasih.

Yang benar,

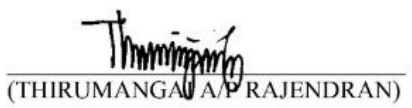

Borang Jawapan Ibu Bapa

Dengan ini, saya Rusimah binti Ibrahim (Nama) ibu bapa/penjaga kepada Muhamad Danish Irfan bin Muhamad Adam (Nama anak) bersetuju menyertai dan membenarkan anak jagaan saya menjadi peserta kajian bagi Penyelidikan Sarjana dengan syarat segala maklumat dirahsiakan mengikut kod etika penyelidikan

Tandatangan ibu bapa/penjaga

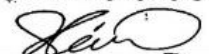

( RUSIMASH BINTIIBRAHIM ) 
APPENDIX E

PARTICIPANTS' CONSENT LETTERS

(PUPILS AND PARENTS)

Thirumangai A/P Rajendran

Pelajar Sarjana Pendidikan (TESL)

Fakulti Pendidikan,

Universiti Kebangsaan Malaysia,

43600 Bangi, Selangor.

Tuan/Puan,

KEBENARAN IBU BAPA/PENJAGA UNTUK MENYERTAI DAN MEMBENARKAN ANAK JAGAAN MENYERTAI KAJIAN PENYELIDIKAN SARJANA

Perkara di atas adalah dirujuk. Saya Thirumangai A/P Rajendran, ingin memohon kebenaran kepada pihak tuan/puan agar memberi kebenaran kepada saya untuk menjalankan kajian tindakan terhadap tuan/puan dan anak jagaan tuan/puan.

2. Tajuk kajian saya ialah "EXPLORING THE OUTCOMES OF USING CHATTERPIXKIDS MOBILE APP ON ESL PUPILS' SPEAKING FLUENCY, MOTIVATION, AND ATTITUDES". Sehubungan dengan itu, tuan/puan dan anak jagaan tuan/puan telah terpilih untuk menjadi peserta kajian ini.

3. Saya memohon kebenaran tuan/puan dan anak jagaan tuan/puan untuk dipilih menjadi peserta kajian penyelidikan Sarjana saya. Segala maklumat peserta kajian akan dirahsiakan mengikut kod etika penyelidikan.

4. Oleh yang demikian, saya amat berharap pihak tuan/puan membenarkan saya menjalankan kajian ini terhadap anak jagaan tuan/puan.

Kerjasama dan perhatian daripada pihak tuan/puan, saya dahulukan dengan ucapan terima kasih.

Yang benar,

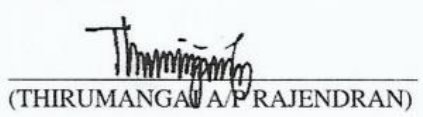

Borang Jawapan Ibu Bapa

Dengan ini, saya SAZICAWATI SALEHUDIN (Nama) ibu bapapenjaga? kepada FIKRI HAMI $2 A N$ (Nama anak) bersetuju menyertai dan membenarkan anak jagaan saya menjadi peserta kajian bagi Penyelidikan Sarjana dengan syarat segala maklumat dirahsiakan mengikut kod etika penyelidikan.

Tandatangan ibu bapa/penjaga

$\frac{\text { Qut }}{\text { (SAZICAWATI SACEHUDIN) }}$ 
APPENDIX F

PARTICIPANTS' CONSENT LETTERS

(PUPILS AND PARENTS)

Thirumangai A/P Rajendran

Pelajar Sarjana Pendidikan (TESL)

Fakulti Pendidikan,

Universiti Kebangsaan Malaysia,

43600 Bangi, Selangor.

Tuan/Puan,

KEBENARAN IBU BAPA/PENJAGA UNTUK MENYERTAI DAN MEMBENARKAN ANAK JAGAAN MENYERTAI KAJIAN PENYELIDIKAN SARJANA

Perkara di atas adalah dirujuk. Saya Thirumangai A/P Rajendran, ingin memohon kebenaran kepada pihak tuan/puan agar memberi kebenaran kepada saya untuk menjalankan kajian tindakan terhadap tuan/puan dan anak jagaan tuan/puan.

2. Tajuk kajian saya ialah "EXPLORING THE OUTCOMES OF USING CHATTERPIXKIDS MOBILE APP ON ESL PUPILS' SPEAKING FLUENCY, MOTIVATION, AND ATTITUDES”. Sehubungan dengan itu, tuan/puan dan anak jagaan tuan/puan telah terpilih untuk menjadi peserta kajian ini.

3. Saya memohon kebenaran tuan/puan dan anak jagaan tuan/puan untuk dipilih menjad peserta kajian penyelidikan Sarjana saya. Segala maklumat peserta kajian akan dirahsiakan mengikut kod etika penyelidikan.

4. Oleh yang demikian, saya amat berharap pihak tuan/puan membenarkan saya menjalankan kajian ini terhadap anak jagaan tuan/puan.

Kerjasama dan perhatian daripada pihak tuan/puan, saya dahulukan dengan ucapan terima kasih.

Yang benar,

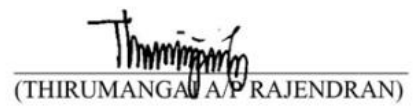

Borang Jawapan Ibu Bapa

Dengan ini, saya Jazmina binti Abdullah (Nama) ibu bapa/penjaga kepada Muhammad Fahim bin Nousath Ali (Nama anak) bersetuju menyertai dan membenarkan anak jagaan saya menjadi peserta kajian bagi Penyelidikan Sarjana dengan syarat segala maklumat dirahsiakan mengikut kod etika penyelidikan.

Tandatangan ibu bapa/penjaga

Omina

(JAZMIQA BINTI ABDULLAH) 


\section{APPENDIX G}

PARTICIPANTS' CONSENT LETTERS

(PUPILS AND PARENTS)

Thirumangai A/P Rajendran

Pelajar Sarjana Pendidikan (TESL)

Fakulti Pendidikan,

Universiti Kebangsaan Malaysia,

43600 Bangi, Selangor.

Tuan/Puan,

KEBENARAN IBU BAPA/PENJAGA UNTUK MENYERTAI DAN MEMBENARKAN ANAK JAGAAN MENYERTAI KAJIAN PENYELIDIKAN SARJANA

Perkara di atas adalah dirujuk. Saya Thirumangai A/P Rajendran, ingin memohon kebenaran kepada pihak tuan/puan agar memberi kebenaran kepada saya untuk menjalankan kajian tindakan terhadap tuan/puan dan anak jagaan tuan/puan.

2. Tajuk kajian saya ialah "EXPLORING THE OUTCOMES OF USING CHATTERPIXKIDS MOBILE APP ON ESL PUPILS' SPEAKING FLUENCY, MOTIVATION, AND ATTITUDES". Sehubungan dengan itu, tuan/puan dan anak jagaan tuan/puan telah terpilih untuk menjadi peserta kajian ini.

3. Saya memohon kebenaran tuan/puan dan anak jagaan tuan/puan untuk dipilih menjadi peserta kajian penyelidikan Sarjana saya. Segala maklumat peserta kajian akan dirahsiakan mengikut kod etika penyelidikan.

4. Oleh yang demikian, saya amat berharap pihak tuan/puan membenarkan saya menjalankan kajian ini terhadap anak jagaan tuan/puan.

Kerjasama dan perhatian daripada pihak tuan/puan, saya dahulukan dengan ucapan terima kasih.

Yang benar,

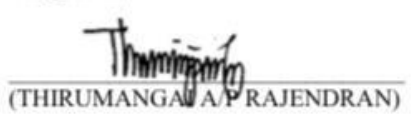

Borang Jawapan Ibu Bapa

Dengan ini, saya

Siti Sufiah Binti Abdul Rahim

(Nama) ibu bapa/penjaga kepada Muhammad Ha'il Sheikhal Bin Md Hafiz (Nama anak) bersetuju menyertai dan membenarkan anak jagaan saya menjadi peserta kajian bagi Penyelidikan Sarjana dengan syarat segala maklumat dirahsiakan mengikut kod etika penyelidikan.

Tandatangan ib bapa/penjaga

(SITI SUFIAH BINTIABDUL RAHIM 
APPENDIX H

PARTICIPANTS' CONSENT LETTERS

(PUPILS AND PARENTS)

Thirumangai A/P Rajendran

Pelajar Sarjana Pendidikan (TESL)

Fakulti Pendidikan,

Universiti Kebangsaan Malaysia,

43600 Bangi, Selangor.

Tuan/Puan,

KEBENARAN IBU BAPA/PENJAGA UNTUK MENYERTAI DAN MEMBENARKAN ANAK JAGAAN MENYERTAI KAJIAN PENYELIDIKAN SARJANA

Perkara di atas adalah dirujuk. Saya Thirumangai A/P Rajendran, ingin memohon kebenaran kepada pihak tuan/puan agar memberi kebenaran kepada saya untuk menjalankan kajian tindakan terhadap tuan/puan dan anak jagaan tuan/puan.

2. Tajuk kajian saya ialah "EXPLORING THE OUTCOMES OF USING CHATTERPIXKIDS MOBILE APP ON ESL PUPILS' SPEAKING FLUENCY, MOTIVATION, AND ATTITUDES". Sehubungan dengan itu, tuan/puan dan anak jagaan tuan/puan telah terpilih untuk menjadi peserta kajian ini.

3. Saya memohon kebenaran tuan/puan dan anak jagaan tuan/puan untuk dipilih menjadi peserta kajian penyelidikan Sarjana saya. Segala maklumat peserta kajian akan dirahsiakan mengikut kod etika penyelidikan.

4. Oleh yang demikian, saya amat berharap pihak tuan/puan membenarkan saya menjalankan kajian ini terhadap anak jagaan tuan/puan.

Kerjasama dan perhatian daripada pihak tuan/puan, saya dahulukan dengan ucapan terima kasih.

Yang benar,

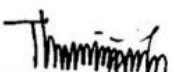

(THIRUMANGAU A RAJENDRAN)

Borang Jawapan Ibu Bapa

Dengan ini, saya SITI JULIANA BINTI YENG (Nama) ibu bapa/penjaga kepada NUR FADHILAH BINTI CHARI NASIP (Nama anak) bersetuju menyertai dan membenarkan anak jagaan saya menjadi peserta kajian bagi Penyelidikan Sarjana dengan syarat segala maklumat dirahsiakan mengikut kod etika penyelidikan.

Tandatangan ibu bapa/penjaga

$$
\text { Qulie }
$$

( SITI ULIANA BINTI YENG ) 